\title{
Occurrence of clubroot and Plasmodiophora brassicae Wor. races in Finland
}

\author{
ANNIKKI LINNASALMI and ANNELI TOIVIAINEN \\ Agricultural Research Centre, Institute of Plant Protection, \\ Plant Pathology Section \\ Jokioinen, Finland
}

\begin{abstract}
Examination of clubroot in cruciferous vegetables in Finland in 1974-1978 revealed the disease in $81 \%$ of the 101 communes inspected. The disease was most common in southern and central Finland, but was also discovered in the northern parts of the region in which cruciferous crops were cultivated $\left(66-67^{\circ} \mathrm{N}\right.$. lat.). Clubroot was found in $65 \%$ of the 375 plant samples collected. It occurred in $68 \%$ of the samples of the most commonly cultivated vegetable, cabbage (56\% of the material), in $63 \%$ of the cauliflower samples ( $22 \%$ of the material), in $56 \%$ of the samples of other cole species (13\% of the material) and in $64 \%$ of the samples of cruciferous root crops (10\% of the material). $P$. brassicae race determinations were performed on 90 samples. The classification system of WiLliams (1966) was applied. The races that were isolated were $1,2,3,4,6$ and 7 . Race 2 was by far the most common, being found in 32 communes; races 3, 4, 6 and 7 were each found in 9-12 communes; race 1 only in one commune. No clear differences in the occurrence of the races in the various parts of the country could be observed. A comparison is made between Williams' and the ECD (BUCZACKI et al. 1975) classification systems. In addition, the pathotypes in clubroot material from Norway and Iceland were determined.
\end{abstract}

Index words: clubroot, Plasmodiophora brassicae Wor., pathotypes, races, cruciferous vegetables

\section{Introduction}

The records on the occurrence of clubroot disease in Finland date back to the 1860s (JAMALAINEN 1936). It is assumed that the disease came to Finland from the east, from Russia (RAINIO 1930). In his studies on the cause of crucifer hernia, Woronin (1878) mentions that cabbage plant materials used by him came from the regions of St. Petersburg (Leningrad) and Wiborg ${ }^{1}$ in Finland. According to the information collected by the Department of Plant Pathology, Agricultural Research Centre, clubroot had spread all over the country, including the western regions, by the $1930 \mathrm{~s}$

\footnotetext{
1 Since 1944 that area has been part of the Soviet Union.
} 
(Rainio 1930, Jamalainen 1936). In the 1930s the susceptibility of cruciferous vegetable cultivars and wild Brassicaceae plants to the fungus Plasmodiophora brassicae Wor. was also studied at the Research Centre. In addition, experiments for chemical control of the disease were carried out (JAMALAINEN 1936). The efficiency of new pesticides was studied in 1944-1977 (LinNASALMI 1948, 1952, 1959; Linnasalmi and Titttanen 1960; MurtomaA and UоTI 1972; annual reports of the Department of Plant Pathology of the Agricultural Research Centre 1960-1977, mimeographs).

A preliminary study on $P$. brassicae races in Finland had been carried out in the years 1971-1972 (Linnasalmi and Palonen 1974).

In this study, the occurrence of clubroot and the pathotypes of $P$. brassicae in cruciferous vegetables in Finland in 1974-1978 were examined. In addition, the pathotypes in clubroot material sampled in Norway and Iceland were determined.

The study is a part of the Nordic clubroot project, NKJ project $271974-1977$, of the Nordic Joint Committee for Agricultural Research: Breeding for clubroot resistance, Plasmodiophora brassicae Wor. races, and the efficiency of new pesticides.

\section{Materials and methods}

\section{Collection of the basic material}

Most of the material for studying the distribution of clubroot was collected by inspecting cruciferous vegetable fields throughout Finland during the growing season, from June to October. A small part of the material, about $2 \%$, was sent in by agricultural research stations, advisers of agricultural information organizations and farmers. The inspections chiefly focused on large cole and root crop farms, but a considerable number of small farmers' crucifer fields were also inspected. The research material collected as described above can be assumed to give a general picture of the distribution of clubroot disease and the $P$. brassicae races in the period under study in the 1970s in Finland.

Samples of galls from the various cultivars affected with clubroot were taken for the analysis of $P$. brassicae races.

\section{Propagation of $P$. brassicae club material and preparation of the inoculum}

The young galls of the original samples were washed thoroughly with running water. They were crushed to prepare a water suspension, which was used to inoculate a steamed (at $100^{\circ} \mathrm{C}$ for $1 \mathrm{~h}$ ) soil-peat medium. From the samples for race analysis additional club material was grown on the original plant species and, if possible, on the original cultivar or on a cultivar known to be susceptible to $P$. brassicae, such as cabbage cv. Ditmarsk and cauliflower cv. Erfurter. To check and ensure the viability of the inocula, the black mustard (Brassica nigra (L.) W.D.J. Косн) breeding line Sv. 72-6842 of the Swedish Seed Association, Sweden, which was very susceptible to clubroot, was also used as a host plant both during the propagation of club materials and later in identification tests of $P$. brassicae races.

During the initial stage of the study, the inoculation of the host was repeated two or three times as five-week growth periods. As the sampling technique improved, the club material from the first propagation could be used as basic material to grow callus cultures and small-club material. The material was stored at $-18^{\circ} \mathrm{C}$.

The callus cultures were prepared from young galls, $1-2 \mathrm{~cm}$ long, which were surface-disinfected with ethanol $\left(\mathrm{C}_{2} \mathrm{H}_{5} \mathrm{OH}\right.$, $94 \%)$ and mercuric chloride $\left(\mathrm{HgCl}_{2}, 1 \%\right)$ and rinsed with distilled water. Small pieces, ca. $2 \mathrm{~mm}$ in diameter, were cut from the inside of the galls, treated with ethanol $(99.5 \%)$ for a few seconds and rinsed with distilled water. The pieces were placed in Erlenmeyer flasks or test tubes on an agar medium. The nutrient solution used was a modification of the solution of Murashige and SKoog (1962), 
in which 3-indoleacetic acid had been replaced with 1-naphthylacetic acid. Coconut milk (100 $\mathrm{ml} / \mathrm{l}$ ) was added because our tests had shown that it increased the growth rate of callus tissue considerably. The cultures were incubated in the dark at ca. $22^{\circ} \mathrm{C}$. Small pieces of callus tissue were transferred every 7 to 10 days to a fresh culture medium, the passages totalling three to four. The callus material was stored at $-5^{\circ} \mathrm{C}$.

Small-club inoculum material was made direct from young fresh or frozen $\left(-18^{\circ} \mathrm{C}\right)$ galls, which were washed with running water and rinsed with distilled water.

For preparing the inoculum, the callus and small-club materials were crushed mechanically, suspended in distilled water and filtered through a nylon filter cloth. The filtrate was centrifuged ( $2400 \mathrm{~g}, 7 \mathrm{~min}$.) three to four times. Before each test, the suspension used was diluted to a concentration of $10^{8}$ spores per $\mathrm{ml}$, using a hemocytometer.

\section{Isolation and identification of races}

\section{Method}

The isolation and identification of races was carried out according to the system of WILLIAMS (1966), a method based on selecting four Brassicaceae plants as differential hosts and studying their resistance or susceptibility to $P$. brassicae.

The test plants were cabbage (Brassica oleracea L. convar. capitata (L.) Alef.), cultivars Jersey Queen and Badger Shipper, and swede (Brassica napus L. var. napobrassica (L.) Rchb.), cultivars Laurentian and Wilhelmsburger. On the basis of 16 possible interactions, 16 races can be isolated and classified according to the following scheme (WILliams 1966).

The use of genetically uniform, homozygous differential host material is a prerequisite for the reliability of the race determinations. The seed material used in this study was

Possible host reactions to infection by races of Plasmodiophora brassicae.

\begin{tabular}{lllllllllllllllllll}
\hline Differential & \multicolumn{11}{c}{ Race } \\
\cline { 2 - 11 } & & 1 & 2 & 3 & 4 & 5 & 6 & 7 & 8 & 9 & 10 & 11 & 12 & 13 & 14 & 15 & 16 \\
\hline Cabbage: & Jersey Queen & + & + & + & + & - & + & + & - & - & + & - & + & - & - & - & - \\
& Badger Shipper & - & + & - & + & - & - & + & - & - & + & + & - & + & + & + & - \\
Rutabaga: & Laurentian & + & + & + & + & - & - & - & + & + & - & + & - & + & - & - & - \\
& Wilhelmsburger & + & - & - & + & - & - & - & - & + & + & + & + & - & + & - & + \\
\hline
\end{tabular}

+ Indicates a susceptible host reaction; - indicates a resistant host reaction.

supplied by NKJ project member Dr. R. JÖNSSON, and produced or acquired by the Swedish Seed Association (nowadays Svalöf AB), Svalöv, Sweden.

\section{Testing}

The tests were carried out in a glasshouse, mean temperature $22^{\circ} \mathrm{C}\left(20-24^{\circ} \mathrm{C}\right)$. When necessary (in winter), Osram HQL 400 W/R mercury high-pressure lamps were used for supplementary lighting.

The growing medium, Enhetsjord $\mathrm{K}$ (AB W. Plantin \& Co, Oxie, Sweden), was a fully fertilized, fine-grained mixture of clay and peat, $\mathrm{pH} 6.3 \pm 0.2$. It was steamed at $100^{\circ} \mathrm{C}$ for $1 \mathrm{~h}$. Seeds of differential hosts were sown in $9 \times 9 \mathrm{~cm}$ pots of thermosetting plastic, 10 seeds/pot, four replicates. Each pot had a plastic tray of its own. Inoculation with the spore suspension, $10 \mathrm{ml} /$ pot, was performed after the sowing and the seeds were covered with a $0.5 \mathrm{~cm}$ layer of the growing medium. Throughout the growing period, the plants were watered by pouring water into the trays to keep the moisture even and to prevent the possibility of cross-contamination.

The growing period was from four to six weeks. The galls were well developed, the 
average size being 0.5 to $1.0 \mathrm{~cm}^{3}$. They were light in colour and usually contained a great number of spores.

To conclude the test, the roots were washed with running water and rinsed with distilled water. The degree of clubroot infection of each plant was assessed on a scale of $0-3$, and the clubroot index was calculated according to Williams (1966):

clubroot index $\frac{0 \times \mathrm{n}_{0}+10 \times \mathrm{n}_{1}+60 \times \mathrm{n}_{2}+100 \times \mathrm{n}_{3}}{\mathrm{n}_{0}+\mathrm{n}_{1}+\mathrm{n}_{2}+\mathrm{n}_{3}}$

$\mathrm{n}_{0}=$ no clubs

$\mathrm{n}_{1}=\mathrm{a}$ few smatl clubs on the secondary roots

$\mathrm{n}_{2}=$ considerable clubbing on the lateral roots

$\mathrm{n}_{3}=$ severe clubs on the primary and secondary roots

This was the primary analysis. The clubs from the replicates of each differential host were combined to make a spore suspension, which was used to re-inoculate all four differential host plants, in accordance with the following scheme:

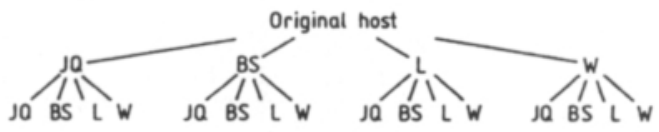

If the result of this cross-testing was similar to that of the primary analysis with respect to both degree of infection and clubroot index, the race determination could be considered to be reliable. If the result was not similar, the cross-testing was repeated three to four times. $^{2}$

\section{Comparison with the ECD classification} system

Comparison with the ECD classification system, developed by the International Clubroot Working Group (BuCZACKI et al. 1975)

\footnotetext{
${ }_{2}$ Purified and identified race material was sent to the Scandinavian members of this project from 1974 onwards to be used in their resistance breeding work. Since 1980 the type isolate material has been deposited in the race bank at the Swedish University of Agricultural Sciences, Department of Resistance Biology, Alnarp, Sweden.
}

was performed with some of our $P$. brassicae isolates (totalling 12) classified by Williams' system. The seeds of ECD differential hosts in Brassica campestris, B. napus and B. oleracea groups (totalling 15 hosts) were received in 1976 from Dr. H. Toxopeus, Instituut de Haaff, Stichting voor Plantenveredeling, Wageningen, the Netherlands.

The test arrangement and the growth conditions were the same as in the tests performed with Williams' method (p. 417).

\section{Results and their evaluation}

\section{Occurrence of clubroot}

\section{Regional distribution}

Of the 192 farms, $61 \%$, and of the collected plant samples, altogether 375, $65 \%$, showed occurrence of clubroot (Table 1, Fig. 1). Thus the study revealed that clubroot was quite common all over Finland. Although the locations inspected were distributed over the country, the number of samples from the various areas differed so much that it is impossible to draw far-reaching conclusions about regional differences in the occurrence of the disease. It can, however, be noted that clubroot was fairly common in the old, densely populated farming areas, Uusimaa (N), Varsinais-Suomi (Ab) and Etelä-Häme ( $\mathrm{Ta})$, and also in Etelä-Savo (Sa) and Etelä-Karjala (Ka). The disease was more severe in eastern Finland than in western Finland. This was possibly partly caused by cultivation techniques, mainly by the fewer opportunities for crop rotation on the farms in eastern Finland. In these areas many farmers had to give up the production of cruciferous vegetables altogether because of clubroot disease in the 1960 s and 70 s.

It also turned out that clubroot was often more common, and even more severe, on smaller than on larger farms, one probable reason being the limited opportunities for crop rotation. This was evident, for example, in gardens around population centres, where var- 
Table 1. Distribution of clubroot and occurrence of Plasmodiophora brassicae Wor. races in Finland, $1974-1978$.

\begin{tabular}{|c|c|c|c|c|c|c|c|c|c|c|c|c|c|c|}
\hline \multirow{3}{*}{\multicolumn{2}{|c|}{$\begin{array}{l}\text { Biological } \\
\text { province' }\end{array}$}} & \multirow{2}{*}{\multicolumn{2}{|c|}{$\begin{array}{l}\text { Communes } \\
\text { inspected }\end{array}$}} & \multirow{2}{*}{\multicolumn{2}{|c|}{$\begin{array}{c}\text { Farms } \\
\text { inspected }\end{array}$}} & \multirow{2}{*}{\multicolumn{2}{|c|}{ Samples }} & \multicolumn{6}{|c|}{$P$. brassicae races } & \multirow[b]{2}{*}{$1-7$} \\
\hline & & & & & & & & 1 & 2 & 3 & 4 & 6 & 7 & \\
\hline & & $\begin{array}{c}\text { total } \\
\text { no. }\end{array}$ & $\begin{array}{c}\text { with } \\
\text { clubroot } \\
\%\end{array}$ & $\begin{array}{c}\text { total } \\
\text { no. }\end{array}$ & $\begin{array}{c}\text { with } \\
\text { clubroot } \\
\%\end{array}$ & $\begin{array}{c}\text { total } \\
\text { no. }\end{array}$ & $\begin{array}{c}\text { with } \\
\text { clubroot } \\
\%\end{array}$ & \multicolumn{6}{|c|}{ no. of isolates } & total \\
\hline $\mathrm{Ab}$ & Varsinais-Suomi & 13 & 100 & 19 & 100 & 46 & 100 & 0 & 6 & 1 & 2 & 2 & 1 & 12 \\
\hline $\mathrm{N}$ & Uusimaa & 6 & 100 & 11 & 100 & 28 & 100 & 0 & 3 & 1 & 2 & 0 & 1 & 7 \\
\hline $\mathrm{Ka}$ & Etelä-Karjala & 4 & 100 & 9 & 56 & 14 & 71 & 0 & 3 & 1 & 0 & 0 & 0 & 4 \\
\hline St & Satakunta & 12 & 75 & 21 & 48 & 26 & 42 & 0 & 4 & 0 & 4 & 0 & $\mathbf{0}$ & 8 \\
\hline $\mathrm{Ta}$ & Etelä-Häme & 20 & 95 & 37 & 73 & 88 & 77 & 0 & 11 & 0 & 1 & 8 & 3 & 23 \\
\hline $\mathrm{Sa}$ & Etelă-Savo & 8 & 50 & 13 & 54 & 20 & 55 & 0 & 1 & 4 & 0 & 0 & 1 & 6 \\
\hline Oa & Etelä-Pohjanmaa & 12 & 58 & 27 & 37 & 44 & 32 & 0 & 2 & 0 & 2 & 0 & 2 & 6 \\
\hline $\mathrm{Tb}$ & Pohjois-Hăme & 9 & 56 & 25 & 24 & 46 & 24 & 0 & 1 & 0 & 1 & 0 & 2 & 4 \\
\hline $\mathrm{Sb}$ & Pohjois-Savo & 7 & 100 & 10 & 80 & 19 & 84 & 1 & 1 & 4 & 0 & 2 & $\mathbf{0}$ & 8 \\
\hline $\mathrm{Kb}$ & Pohjois-Karjala & 6 & 83 & 10 & 60 & 23 & 52 & 0 & 7 & 1 & 0 & 0 & 0 & 8 \\
\hline $\mathrm{Om}$ & Keski-Pohjanmaa & 2 & 50 & 5 & 60 & 6 & 50 & 0 & 1 & 0 & 0 & 0 & 0 & 1 \\
\hline $\mathrm{Ob}$ & Pohjois-Pohjanmaa & 2 & 100 & 5 & 100 & 15 & 100 & 0 & 0 & 0 & 0 & 2 & 1 & 3 \\
\hline \multicolumn{2}{|c|}{ total/mean } & 101 & 81 & 192 & 61 & 375 & 65 & 1 & 40 & 12 & 12 & 14 & 11 & 90 \\
\hline
\end{tabular}

I Heikinheimo and Raatikainen (1971).

ious cole species and cruciferous root crops had been grown in the same fields for many years.

\section{Clubroot in different plant species}

Cruciferous vegetables are cultivated almost throughout Finland up to $66-67^{\circ} \mathrm{N}$. lat., but the main production takes place in the southern part of the country. The areas of the most commonly cultivated crops in 1974-1978 (mean) are presented below (Statistics of the National Board of Agriculture (Finland).)

\begin{tabular}{lccc}
\hline & cabbage & cauliflower & swede \\
\hline $\begin{array}{l}\text { Southern Finland } \\
\text { Ab N Ka St Ta Sa }\end{array}$ & 554 & 328 & 1164 \\
$\begin{array}{l}\text { Central Finland } \\
\begin{array}{l}\text { Oa Tb Sb Kb } \\
\text { Northern Finland }\end{array}\end{array}$ & 118 & 23 & 733 \\
$\begin{array}{l}\text { Om Ob Ok } \\
\text { Total area ha }\end{array}$ & 701 & 10 & 72 \\
\hline
\end{tabular}

In the 1980s, the areas of cabbage and cauliflower remained roughly the same, totalling some $1000 \mathrm{ha}$. The area of swede decreased markedly, from almost 2000 to 400 ha. The cultivation of Chinese cabbage increased to $600 \mathrm{ha}$. The total area of the other cole species was some 80 ha and that of radish and turnip totalled some 40 ha.

The data on the occurrence of clubroot in different plant species are presented in Table 2. Clubroot was found in $68 \%$ of the cabbage samples, in $63 \%$ of the cauliflower samples, in $56 \%$ of the samples of other cole species, and in $64 \%$ of the root crop samples. The distribution and number of samples from different plant species roughly indicate the frequency of cultivation of these crops.

\section{Plasmodiophora brassicae races and their occurrence}

As in practice it was not possible, within the limits of the study, to carry out a race determination of every clubroot sample, the samples for tests were chosen to represent as many communes as possible in each biological prov- 


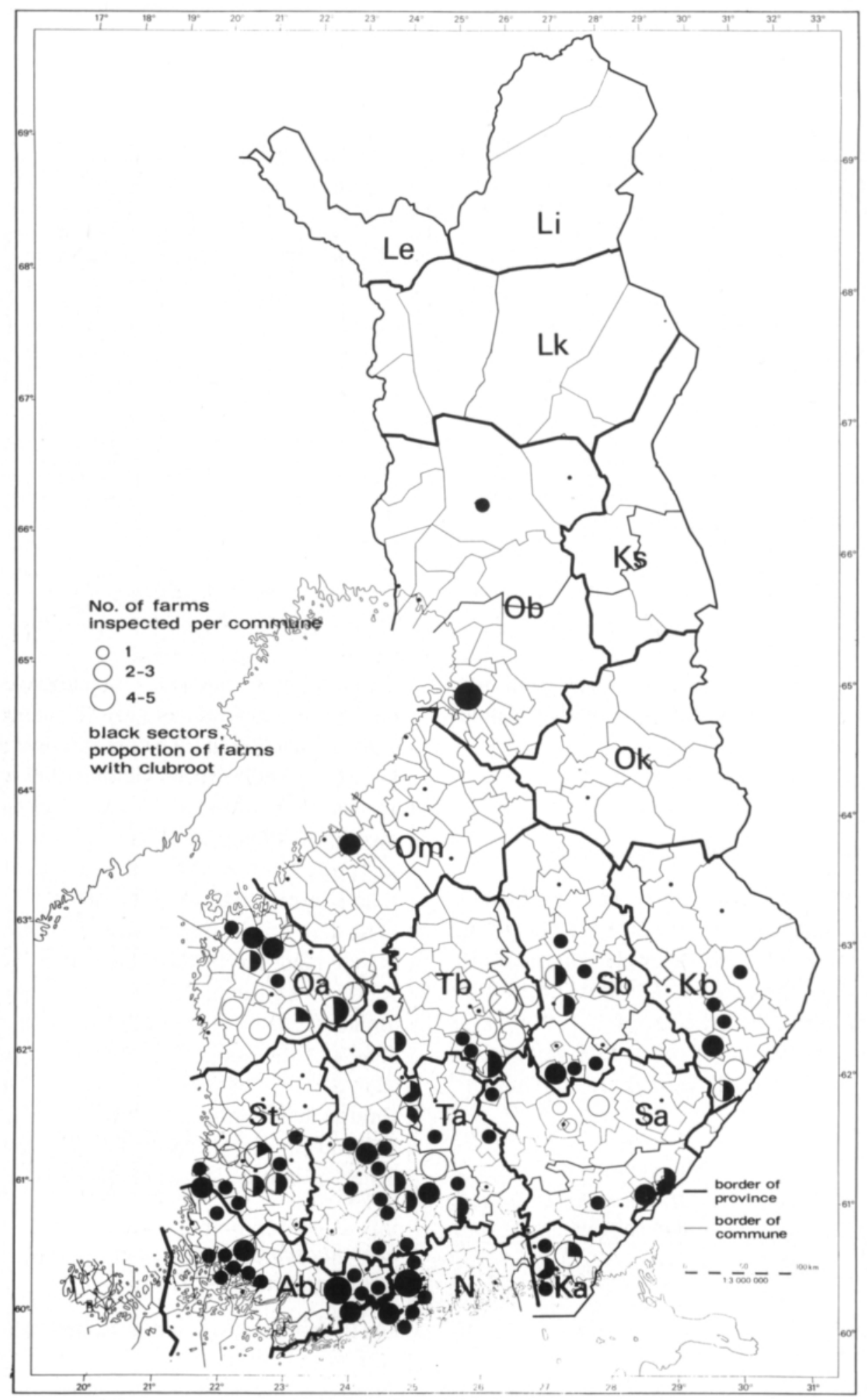

Fig. 1. Location of inspected farms growing cruciferous vegetables and occurrence of clubroot in Finland, 1974 -1978 . 
Table 2. Occurrence of clubroot in different plant species.

\begin{tabular}{|c|c|c|c|c|}
\hline \multirow[t]{2}{*}{ Species } & \multicolumn{2}{|c|}{ Samples } & \multicolumn{2}{|c|}{ Plant species } \\
\hline & $\begin{array}{c}\text { total } \\
\text { number }\end{array}$ & $\begin{array}{c}\text { with } \\
\text { clubroot }\end{array}$ & $\begin{array}{c}\% \text { of } \\
\text { samples }\end{array}$ & $\begin{array}{l}\% \text { with } \\
\text { clubroot }\end{array}$ \\
\hline Cabbage & 209 & 143 & 56 & 68 \\
\hline Cauliflower & 82 & 52 & 22 & 63 \\
\hline Broccoli & 21 & $10)$ & & \\
\hline Red cabbage & 10 & 8 & & \\
\hline Brussels sprouts & 8 & 4 & & \\
\hline Kohlrabi & 3 & 3 & 13 & 56 \\
\hline Curly kale & 3 & 1 & & \\
\hline Marrowstem kale & 2 & 1 & & \\
\hline Chinese cabbage & 1 & 0 & & \\
\hline Swede & 28 & $16)$ & & \\
\hline Turnip & 5 & 4 & & \\
\hline Fodder turnip & 1 & 1 & 10 & 64 \\
\hline \multirow[t]{2}{*}{ Radish } & 2 & 2 & & \\
\hline & 375 & 245 & & \\
\hline
\end{tabular}

ince, altogether 69 communes, or $84 \%$ of the communes where clubroot was found. Most determinations were performed on club samples of the crucifers cultivated most frequently: cabbage and cauliflower. Some additional determinations were made on samples taken from less common species. The number of P. brassicae isolates totalled 90 .

\section{Races}

The races isolated were $1,2,3,4,6$ and 7 (Appendix 1). The identification results for races 1, 2, 4 and 7 were clear. The test results for races 3 and 6 showed some deviation from the classification scheme. Several isolates from both of these races showed slight contamination in Badger Shipper, although according to the scheme this differential host should have been resistant to these races.

As the identification tests with certain isolates of other races also showed more variation in the clubroot indices in Badger Shipper than in other differential hosts, it seems that the seed material of Badger Shipper may have had some genetic heterogeneity. It is also possible that the isolate materials classified as races 3 and 6 included some pathotypes that were variants of the main races. The possibil- ity of mutation in the differential hosts or in the purified $P$. brassicae race isolates must also be taken into account.

A preliminary report on the occurrence of $P$. brassicae races determined in the present study was presented at the Brassica conference 1981 (Linnasalmi and Toiviainen 1981).

\section{Regional distribution}

The regional distribution of the races is shown in Table 1 and on the map in Fig. 2. The communes from which the samples were taken and data on the original host are given in App. 1. Of the six races isolated, race 2 was by far the most common. It was found in 32 communes, i.e. in $46 \%$ of the communes with clubroot. Races 3, 4, 6 and 7 were each found in about ten communes (9-12 communes, i.e. $14-17 \%$ ); race 1 occurred only once. Two different races were found in only a few communes: races 2 and 3 in Nurmijärvi $(\mathrm{N})$ and Joutseno $(\mathrm{Sa})$, races 2 and 6 in Haukivuori (Sb), races 6 and 7 in Hartola (Ta), Kangasala (Ta) and Oulu (Ob). On the basis of this study, no clear prevalence of races can be demonstrated in different parts of Finland. All races were distributed fairly evenly over the country, with the exception of the 


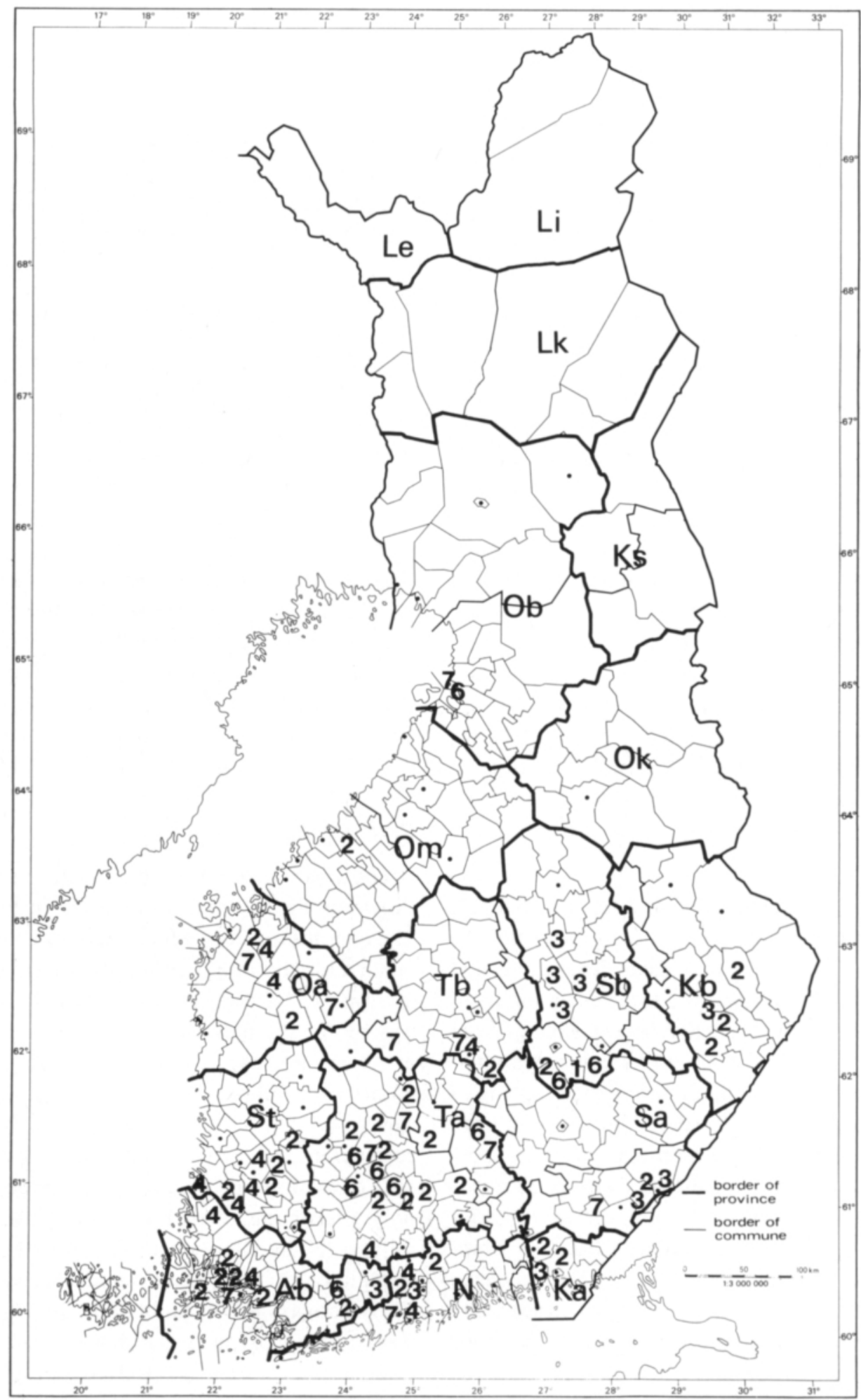

Fig. 2. Occurrence of Plasmodiophora brassicae Wor. races in Finland, 1974-1978. 
rare race 1 . However, race 4 seems to show some prevalence in the western parts of the country, while race 3 occurs mostly in the east.

In the preliminary studies conducted in 1971 -1972 on the occurrence of the $P$. brassicae races in Finland (Linnasalmi and Palonen 1974), the races 2, 4, 6 and 7 were isolated. In two test places the races that were found in 1972 were, according to the present study, still the same, viz. race 4 in the test field of the Institute of Plant Pathology in Tikkurila (Vantaa) and race 7 in the test field of the Institute of Horticulture in Piikkiö. Ten years earlier, in 1964, samples from these localities were sent to Prof. P.H. Williams. He identified race 7 from Piikkiö and race 2 from Tikkurila (Williams 1966).

\section{Occurrence in different plant species}

The races displayed the following distribution by different plant species: races $2,3,4$, 6 and 7 were isolated from cabbage (60 isolates) and cauliflower (17 isolates); races 2, 3 and 7 from broccoli (4 isolates); race 4 from red cabbage and marrowstem kale (1 isolate from each); races 1,2 and 4 from swede (5 isolates); and race 2 from turnip (2 isolates).

Of the cabbage cultivars grown in Finland, (cf. App. 2) only the Norwegian Resista and Respla (WEISAETH 1977) are partly resistant to some $P$. brassicae races. These cultivars were accepted for marketing in Norway in 1973 and in Finland in 1975. In our infection tests (glasshouse tests) with some of the $P$. brassicae races occurring in Finland, both cultivars were found to have some resistance to races 2, 4 and 7 when compared with the severely contaminated Blåtopp cultivar:

\begin{tabular}{llccc}
\hline race (isol.) & \multicolumn{3}{c}{ cultivar, clubroot index $(0-3)$} \\
\cline { 3 - 5 } & & Resista & Respla & $\begin{array}{c}\text { Blåtopp } \\
\text { (control) }\end{array}$ \\
\hline 2 & (F 118) & 1.80 & 1.47 & 2.88 \\
3 & (F 147) & 2.36 & 2.49 & 2.96 \\
4 & (F 155) & 1.95 & 1.14 & 2.78 \\
7 & (F 171) & 1.86 & 0.84 & 2.52 \\
\hline
\end{tabular}

In some farms where these cultivars were grown in field sectors situated next to each other, severe contamination and consequently weaker growth of Blåtopp were evident, whereas Resista and Respla were only sparsely and slightly contaminated, and headed well.

The occurrence of $P$. brassicae races determined according to Williams' system in other countries

\section{Norway and Iceland}

According to the working plan of NKJ project 27, the determination of $P$. brassicae races in Norwegian material was performed in Finland. The samples had mostly been taken from resistance breeding test fields in different parts of the country by the Norwegian project member, First Amanuensis G. Weisaeth. Half of the samples represented the breeding lines of cabbage. The test fields were located in 17 communes, and the number of samples totalled 38 .

The race distribution was as follows:

\begin{tabular}{lcrl}
\hline race & $\begin{array}{c}\text { communes } \\
\text { no. }\end{array}$ & $\begin{array}{c}\text { isolates } \\
\text { no. }\end{array}$ & host plants \\
\hline 1 & 5 & 6 & cabbage, swede \\
2 & 3 & 5 & cabbage, swede, rape \\
4 & 13 & 21 & $\begin{array}{l}\text { cabbage, cauliflower, } \\
\text { kohlrabi, swede }\end{array}$ \\
7 & 3 & 5 & cabbage \\
9 & 1 & 1 & swede \\
\hline
\end{tabular}

Detailed results from the race determinations of the Norwegian material, together with purified club material, were supplied annually to the Department of Vegetable Crops, Agricultural University of Norway, Ảs, Norway. Some isolates from this material were used in our ECD test series (Table 3).

A report on the occurrence of races 1, 7 and 9 in Norway, in the Trøndelag region, is given in the publication of LINNASALMI and WEISAETH (1978). On the basis of our new sample material (cf. data given above), it would seem that race 4 is more common than the others elsewhere in Norway. There were some 
differences between the Finnish and Norwegian race spectra: race 9 was not found in Finland, and races 3 and 6 , which are fairly common in Finland, were not found in the Norwegian material. However, data on races 3, 5 and 6, as well as races 1 and 9 , are presented in some earlier studies on the Norwegian race spectrum (WeISAETH 1972). Two cabbage samples (WEISAETH's breeding lines) from Iceland were analysed. Only race 7 was found in both samples (LinNASAlmi and Weisaeth 1978).

\section{Sweden}

In connection with breeding work for clubroot resistance in cruciferous oil crops, R. JöNSSON investigated the occurrence of $P$. brassicae races in Skåne, in southern Sweden. Using the method of Williams, Jönsson (1971, 1972) concluded that in the populations collected from various localities there was the possibility of occurrence of several $P$. brassicae races, and definite occurrence of race 15 in one case. Using the callus technique, Jönsson isolated races 1, 2, 3, 4, 6 and 7 (JönsSON 1981).

\section{Other countries}

In addition to the Nordic countries, information about the occurrence of $P$. brassicae races has been published from the following countries: USA: races 6 and 7 (WILliams and Walker 1963, Strandberg and Williams 1967); Canada: races 1, 2, 3, 4, 6 and $6 \mathrm{~A}$ (Ayers 1972), races 2 and 6 (ChIANG and Crête 1972, ReYes et al. 1974); Japan: race 2 (YoshiKawa and Buczacki 1978); GDR: races 1, 3, 4, 6, 7 and 9 (Williams and Seidel 1968); Poland: races 2, 4, 6 and 7 (NowICKI 1978); USSR: races 1, 6 and 7 (KRIVCHENKO et al. 1982). Moreover, mention should be made of the race identifications made by Williams (1966) on materials from the following countries: Czechoslovakia race 6; the UK race 1; FRG race 7; USSR race 2; Australia races 3, 6 and 7; New Zealand races 1, 2 and 4; Japan races 3 and 5 .

\section{Comparison between the WILLIAMS' and ECD classification systems}

In this study with the $P$. brassicae race ma-

Table 3. Comparison between the Williams' and ECD systems.

\begin{tabular}{|c|c|c|c|c|c|c|c|}
\hline \multicolumn{2}{|c|}{ Isolate } & \multirow[t]{2}{*}{ Race } & \multicolumn{4}{|c|}{$\begin{array}{l}\text { Williams' system } \\
\text { Clubr. ind. in diff. hosts }\end{array}$} & $\begin{array}{c}\text { ECD code } \\
\text { Diff. host groups }\end{array}$ \\
\hline & & & JQ & BS & L & W & B.c. B.n. B.o. \\
\hline $\mathbf{N}$ & P74048 C & 1 & 22 & 0 & 83 & 86 & $16-31-12$ \\
\hline $\mathbf{F}$ & 117 & 2 & 97 & 92 & 100 & 0 & $16-03-31$ \\
\hline $\mathbf{F}$ & 118 & 2 & 90 & 93 & 97 & 0 & $16-19-31$ \\
\hline $\mathbf{F}$ & 1 & 2 & 79 & 83 & 97 & 0 & $16-19-31$ \\
\hline $\mathbf{F}$ & 147 & 3 & 96 & 1 & 99 & 0 & $16-18-30$ \\
\hline $\mathbf{F}$ & 155 & 4 & 89 & 68 & 94 & 80 & $16-31-31$ \\
\hline F & 168 & 4 & 76 & 60 & 82 & 74 & $17-31-31$ \\
\hline F & 106 & 6 & 68 & 0 & 0 & 0 & $16-00-30$ \\
\hline F & 171 & 7 & 94 & 86 & 0 & 0 & $16-00-31$ \\
\hline $\mathrm{N}$ & P74046 & 7 & 94 & 88 & 0 & 0 & $16-02-31$ \\
\hline I & P74040 & 7 & 86 & 70 & 0 & 0 & $16-02-31$ \\
\hline I & P74043 & 7 & 91 & 69 & 0 & 0 & $16-03-31$ \\
\hline
\end{tabular}

Diff. host symbols cf. App. 1. B.c. Brassica campestris; B.n. Brassica napus; B.o. Brassica cleracea; ECD codes according to Toxopeus 1974.

Origin of isolates from Finland (F) in App. 1; from Norway (N) P74048 C Jersey Queen (Asker) and P74046 Badger Shipper (Stjørdal); from Iceland (I) P74040 cabbage lines 666 Weisaeth and P74043 line 696 Weisaeth (Hrunamannahreppur). 
terial classified according to Williams' system (1966), a comparative test series was carried out using the ECD classification system (BuCZACKI et al. 1975). Pure isolates of races 1, 2, 3, 4, 6 and 7 (12 in total) were chosen for the tests. The results are shown in Table 3.

In the Brassica campestris group, the resistance and susceptibility of all differential hosts to the various races are the same, code number 16, with exception of one race 4 isolate, for which the code is 17 because of the susceptibility of differential host 01 .

In the Brassica napus group, the differential hosts show more diversity in their reactions to the different races, but there is also variability with regard to isolates of the same race. For example, the codes for race 7 are 00 , 02 and 03 . Number 03 is also the code of one of the isolates of race 2 . For the isolates of race 2 , the reactions of the ECD differential hosts are to a large extent borderline cases between susceptibility and resistance, and therefore the code can be either 03 or 19 . The differential hosts of the group do not serve to separate races 1 and 4 . All are $100 \%$ susceptible, code 31 .

In the Brassica oleracea group, some differences were found. The code numbers are 12, 30 and 31 . Code 12 applies only to race 1 , but code number 30 to both races 3 and 6 , and code 31 to races 2,4 and 7 .

Few results corresponding to those of our ECD test are found in publications from other countries. Code 16-31-12, which corresponds to race 1 in our material (isolate from Norwegian material), has been reported from France (Rouxel et al. 1983). Code 16-31-31, corresponding to one of our race 4 isolates, has been reported from the USA (CAMPBELL et al. 1981) and from Scotland, UK (BROKENSHIRE and LEWIS 1981), and code 17-31-31, corresponding to the other race 4 isolate, also from the UK (BroKENSHIRE and LewIS 1981, Dixon et al. 1981). The codes 16-02-31 and 16-03-31, corresponding to our race 7 (isolates from the Norwegian and Icelandic materials), were reported by DoBson et al. (1983) from the USA. Data on code 16-02-31 have also been reported from Canada by CHIANG and CRETE (1983), who, however, mention it as the ECD code of their race 2 (sensu WILLIAMS). The survey of Toxopeus et al. (1986) of the ECD tests performed mostly in Western Europe up to 1982 includes code 16-31-12 (four occurrences), corresponding to our race 1 ; code 16-19-31 (two occurrences), corresponding to our race 2 ; codes $16-31-31$ and 17-31-31 (65 and 5 occurrences respectively), corresponding to our race 4 ; codes $16-00-31$, 16-02-31 and 16-03-31 (3, 51 and 13 occurrences respectively), corresponding to our race 7 .

In addition to the studies mentioned above, determinations of $P$. brassicae pathotypes by the ECD system have been reported in the following publications: ToxOPEUS (1974) and Toxopeus and JANSEN (1975) from the Netherlands, HEYN (1981) from the FRG, JonEs et al. (1982 a) from the UK, NAIKI et al. (1984) from Japan and LAMMERINK (1986) from New Zealand.

In comparing the advantages and disadvantages of Williams' method with the ECD method for isolating and classifying $P$. brassicae pathotypes, it can be concluded that WILliamS' system is a more time-saving method. By the cross-testing technique described previously (p. 418), it was possible to detect the main pathotypes in a large area (approx. 3000 ha) by means of only four differential hosts. On the other hand, it is evident that with such a restricted set of differential hosts it is not possible to identify all possible pathotypes and pathotype variants with certainty. The ECD system, with its fifteen differential hosts, is much more laborious and the requirement for growing space is many times greater than with Williams' method. Even more serious is the fact that in our comparative test series, which was carried out with very clear and pure race isolates classified according to $\mathrm{W}_{\mathrm{IL}}$ LIAMS' system, the ECD results showed uncertainties and contradictions, as can be seen in Table 3 and in the report of the results.

Soon after introduction of the ECD system, other workers also began to draw attention to 
the uncertainties of the pathotype determinations obtained by the method. The studies of Tinggal and Webster (1981) showed that $P$. brassicae populations identified by the ECD method and assumed to be pure isolates in fact contained several pathotypes. Similarly, DixoN et al. (1981) and Jones et al. (1982 a, b) found mixtures of pathotypes in their collections. Toxopeus et al. (1986) mention uncertainties in coding $P$. brassicae populations by the ECD system. Worth mention is also the critical assessment of the limitations of the ECD method by CRUTE et al. (1980).

\section{Discussion}

Regardless of the classification system employed, one of the most important requirements for the reliable determination of pathotypes is that a genetically uniform inoculum material can be obtained. One way to achieve this is the single spore technique starting from the resting spores of the $P$. brassicae fungus. Difficulties have been encountered in developing the technique. In the studies of BUCZACKI (1977), Tinggal and Webster (1981) and JoNES et al. (1982 b), with ECD population materials, in which Brassica napus and $B$. campestris varieties were used as test plants, the results have not been very promising; the infection rate remained low, $20-30 \%$ at best (Tinggal and Webster). Moreover, Tinggal and Webster found that when two single spore isolates from ECD populations were tested further, roughly one half gave a result that corresponded with the original code, whereas four new races differentiated from one of the populations and two new races from the other.

The single spore technique can obviously be improved, but judging by what is known thus far about the multistage internal life cycle of $P$. brassicae and its development in the host plant (Ingram and Tommerup 1972, IngRAM 1978), and about the microstructure of the fungus as revealed by electron microscopy (Dekhuijzen 1979, Ikegami et al. 1978, Buc-
ZACKI et al. 1979), it may be difficult to achieve a homozygotic fungus material. Theoretically there are many possibilities for different recombinations of differential pathogenicity genes (cf. CRUTE et al. 1980 with references, Tinggal and Webster 1981).

The significance of the genetic properties of the host plants used in the $P$. brassicae infection studies began to receive attention in the 1950s. Macfarlane (1955) concluded that in certain cases the heterogeneity of the host plant population can cause variation in the infection results. In the 1960s Williams (1966), among others, stressed the importance of genetically uniform differential host materials in pathotype determinations. Since our preliminary work on $P$. brassicae races (LINNASAlmi and PALONEN 1974), our aim has been to use homozygotic seed material of the differential hosts (cf. p. 417). This criterion was not always taken into account prior to the 1980s. Difficulties have been encountered in the production of homozygotic test plant lines by conventional methods. According to CRUTE et al. (1980), heterogeneity is apparent in some differential host lines of the $B$. oleracea group, possible in the $B$. campestris group and less likely only in the $B$. napus group, because the species is strongly inbreeding.

However, new developments have improved the prospects of producing homozygotic test plant material that has the appropriate resistance/susceptibility qualities. For instance, the production of haploid plants from anther cultures via embryogenesis will allow rapid establishment of pure lines. So far haploid plants have been obtained from various Brassicaceae species, e.g. B. napus, B. campestris, B. oleracea var. italica (Keller and Armstrong 1977, 1979, 1983), B. oleracea var. gemmifera (OCKENDON 1984) and B. oleracea var. capitata (ChIANG et al. 1985).

The rapid advance of plant molecular biochemistry and genetics offers new opportunities for studying questions of resistance to diseases. One of the new possibilities already in sight is the application of gene technology to 
modify the genom of a plant directly as desired. It remains to be seen how long it will take before the prerequisites exist for applying these techniques in the breeding of clubroot resistant cruciferous vegetable cultivars.
Acknowledgements. This study was partly funded by the National Research Council for Agriculture and Forestry of the Academy of Finland, which we acknowledge with gratitude. We express our sincere thanks to the organizations and persons who have given valuable help in our work. We are especially grateful for the skilful technical assistance of Ms. Kirsti Nieminen. 
Appendix 1. Clubroot (Plasmodiophora brassicae Wor.) races in Finland, 1974-1978.

Differential plants: Jersey Queen JQ, Badger Shipper BS, Laurentian L, Wilhelmsburger W

\begin{tabular}{|c|c|c|c|c|c|c|c|}
\hline \multirow{2}{*}{$\begin{array}{l}\text { Locality } \\
\text { sample no. }\end{array}$} & \multicolumn{2}{|c|}{ Original host } & \multicolumn{4}{|c|}{ Clubroot index ${ }^{1}$} & \multirow[t]{2}{*}{ Race } \\
\hline & species & cultivar & JQ & BS & L & W & \\
\hline \multicolumn{8}{|l|}{ Pohjois-Savo Sb } \\
\hline 193 Virtasalmi & swede & Mustiala & 18 & 0 & 81 & 67 & 1 \\
\hline \multicolumn{8}{|c|}{ Varsinais-Suomi $A b$} \\
\hline 97 Lohja & cauliflower & Erfurter & 56 & 37 & 60 & 0 & 2 \\
\hline 253 Masku & cauliflower & & 87 & 65 & 88 & 0 & 2 \\
\hline 162 Raisio & cauliflower & Flora Blanca & 93 & 94 & 96 & 0 & 2 \\
\hline 169 Rusko & cabbage & Amager, hőg & 99 & 94 & 99 & 0 & 2 \\
\hline 11 Rymăttylă & cauliflower & Flora Blanca & 47 & 68 & 78 & 0 & 2 \\
\hline 163 Sauvo & cauliflower & Flora Blanca & 94 & 97 & 96 & 0 & 2 \\
\hline \multicolumn{8}{|l|}{ Uusimaa $N$} \\
\hline 1 Hyvinkảă & cauliflower & Erfurter & 79 & 83 & 97 & 0 & 2 \\
\hline 76 Nurmijărvi & cabbage & Västernordland & 93 & 87 & 95 & 0 & 2 \\
\hline 86 Nurmijärvi & cabbage & Københavns Torve & 90 & 57 & 77 & 0 & 2 \\
\hline \multicolumn{8}{|l|}{ Eteld-Karjala $\mathrm{Ka}$} \\
\hline 154 Vehkalahti & cabbage & Ruhm von Enkhuizen & 93 & 91 & 94 & 0 & 2 \\
\hline 157 Vehkalahti & swede & Pandur & 87 & 89 & 96 & 0 & 2 \\
\hline 158 Anjalankoski & cabbage & Blátopp Faales & 94 & 94 & 99 & 0 & 2 \\
\hline \multicolumn{8}{|l|}{ Satakunta St } \\
\hline 196 Huittinen & cabbage & Futura & 96 & 96 & 99 & 0 & 2 \\
\hline 224 Kiikka & marrowstem kale & & 78 & 94 & 68 & 0 & 2 \\
\hline 227 Lappi T1 & cauliflower & & 91 & 83 & 85 & 0 & 2 \\
\hline 221 Mouhijărvi & broccoli & Greenia & 53 & 71 & 41 & 0 & 2 \\
\hline \multicolumn{8}{|l|}{ Etela-Häme Ta } \\
\hline 175 Asikkala & cabbage & Københavns Torve & 85 & 70 & 87 & 0 & 2 \\
\hline 176 Asikkala & cabbage & Blåtopp Faales & 95 & 92 & 94 & 0 & 2 \\
\hline 118 Hattula & cabbage & Ruhm von Enkhuizen & 90 & 93 & 97 & 0 & 2 \\
\hline 194 Kuhmoinen & turnip & & 93 & 69 & 96 & 0 & 2 \\
\hline 205 Kuorevesi & turnip & Guldbåll & 95 & 95 & 100 & 0 & 2 \\
\hline 207 Lammi & cabbage & Blâtopp Faales & 84 & 86 & 93 & 0 & 2 \\
\hline 159 Orivesi & cabbage & & 85 & 73 & 92 & 0 & 2 \\
\hline 117 Sahalahti & cabbage & Blåtopp Faales & 97 & 92 & 100 & 0 & 2 \\
\hline 199 Sahalahti & cabbage & Blåtopp & 94 & 89 & 99 & 0 & 2 \\
\hline 209 Tuulos & cabbage & & 93 & 95 & 94 & 0 & 2 \\
\hline 126 Tampere & cabbage & & 98 & 94 & 99 & 2 & 2 \\
\hline \multicolumn{8}{|l|}{ Etelä-Savo Sa } \\
\hline 143 Joutseno & cabbage & Golden Acre & 97 & 29 & 86 & 0 & 2 \\
\hline \multicolumn{8}{|c|}{ Etelä-Pohjanmaa Oa } \\
\hline 233 Jalasjärvi & cauliflower & & 74 & 71 & 67 & 0 & 2 \\
\hline 236 Văhăkyrö & cabbage & & 99 & 99 & 99 & 1 & 2 \\
\hline \multicolumn{8}{|l|}{ Pohjois-Häme Tb } \\
\hline 214 Toivakka & cabbage & & 95 & 56 & 99 & 0 & 2 \\
\hline \multicolumn{8}{|l|}{ Pohjois-Savo Sb } \\
\hline 192 Haukivuori & cabbage & Amager & 81 & 68 & 94 & 0 & 2 \\
\hline \multicolumn{8}{|l|}{ Pohjois-Karjala $\mathrm{Kb}$} \\
\hline 63 Eno & swede & Östgöta & 70 & 49 & 74 & 0 & 2 \\
\hline 182 Pyhäselkă & cabbage & Blâtopp Faales & 93 & 75 & 95 & 0 & 2 \\
\hline 183 Pyhäselkä & cabbage & Văsternordland & 86 & 57 & 94 & 0 & 2 \\
\hline 177 Raaăkkylä & cabbage & Københavns Torve & 95 & 28 & 97 & 0 & 2 \\
\hline 178 Rảảkkylă & cabbage & Blåtopp Faales & 98 & 68 & 94 & 0 & 2 \\
\hline 179 Rảảkkylă & cabbage & Ruhm von Enkhuizen & 81 & 92 & 88 & 0 & 2 \\
\hline 180 Raaăkkylă & cabbage & Golden Acre & 93 & 95 & 98 & 0 & 2 \\
\hline
\end{tabular}

1 Each index is the mean of four replicates. 
species cultivar

Blåtopp Faales

Blåtopp Faales

Blåtopp Faales

Blåtopp Faales

Golden Acre

Västernordland

Greenia

Ruhm von Enkhuizen

Blåtopp Faales

Blâtopp Faales

Waltham

Amager hög

cauliflower

cabbage

swede

cabbage

cauliflower

red cabbage

cauliflower

swede

cabbage

cauliflower

cabbage

Marner Sepco

cabbage

cabbage

cabbage

Sammatti

22 Sammatti

Etela-Hame Ta

55 Hartola

122 Hauho

112 Kangasala

124 Kangasala

106 Pălkäne

107 Pălkăne

108 Palkäne

170 Toijala cabbage

cabbage

cabbage

cabbage

cabbage

cabbage

cabbage

cabbage

JQ BS L W

1 Each index is the mean of four replicates. 


\begin{tabular}{|c|c|c|c|c|c|c|c|}
\hline \multirow{2}{*}{$\begin{array}{l}\text { Locality } \\
\text { sample no. }\end{array}$} & \multicolumn{2}{|c|}{ Original host } & \multicolumn{4}{|c|}{ Clubroot index ${ }^{1}$} & \multirow[t]{2}{*}{ Race } \\
\hline & species & cultivar & JQ & BS & L & W & \\
\hline \multicolumn{8}{|l|}{ Pohjois-Savo Sb } \\
\hline 191 Haukivuori & cabbage & Blåtopp Faales & 57 & 2 & 3 & 0 & 6 \\
\hline 188 Joroinen & cauliflower & Erfurter & 48 & 1 & 0 & 0 & 6 \\
\hline \multicolumn{8}{|c|}{ Pohjois-Pohjanmaa $\mathrm{Ob}$} \\
\hline 67 Oulu & cauliflower & & 84 & 6 & 0 & 0 & 6 \\
\hline 250 Oulu & cabbage & & 100 & 9 & 0 & 0 & 6 \\
\hline \multicolumn{8}{|l|}{ Varsinais-Suomi $A b$} \\
\hline 171 Piikkiö & cabbage & TK 499 Weisaeth & 94 & 86 & 0 & 0 & 7 \\
\hline \multicolumn{8}{|l|}{ Uusimaa $N$} \\
\hline 88 Espoo & cauliflower & & 97 & 19 & 0 & 0 & 7 \\
\hline \multicolumn{8}{|l|}{ Etela-Häme Ta } \\
\hline 174 Hartola & cabbage & Toftegård & 94 & 51 & 0 & 0 & 7 \\
\hline 204 Längelmäki & cauliflower & Erfurter Dvärg & 90 & 13 & 0 & 0 & 7 \\
\hline 38 Kangasala & cabbage & Resista & 100 & 27 & 0 & 0 & 7 \\
\hline \multicolumn{8}{|l|}{ Etelä-Savo Sa } \\
\hline 148 Lemi & cabbage & Blâtopp Faales & 100 & 24 & 2 & 0 & 7 \\
\hline \multicolumn{8}{|l|}{ Etela-Pohjanmaa Oa } \\
\hline 231 Alavus & cabbage & & 84 & 64 & 3 & 1 & 7 \\
\hline 238 Laihia & cabbage & Futura & 99 & 31 & 0 & 0 & 7 \\
\hline \multicolumn{8}{|l|}{ Pohjois-Häme Tb } \\
\hline 216 Jyväskylăn mlk & broccoli & & 98 & 16 & 3 & 0 & 7 \\
\hline 211 Keuruu & cabbage & Blåtopp Faales & 100 & 21 & 0 & 0 & 7 \\
\hline \multicolumn{8}{|c|}{ Pohjois-Pohjanmaa $\mathrm{Ob}$} \\
\hline 248 Oulu & cauliflower & Erfurter Dvărg & 97 & 57 & 3 & 0 & 7 \\
\hline
\end{tabular}

Each index is the mean of four replicates. 
Appendix 2. The list of species and cultivars.

Scientific nomenclature according to Zander Handwörterbuch der Pflanzennamen (ENCKE et al. 1981).

Cabbage

Red cabbage

Cauliflower

Broccoli

Brussels sprouts

Kohlrabi

Curly kale

Marrowstem kale

Chinese cabbage

Swede

Turnip

Radish

\section{Brassica oleracea $\mathrm{L}$.}

convar. capitata (L.) Alef.

var. capitata: Amager, Amager hög, Amager Stenhoved, Amager Toten, Blåtopp, Blåtopp Faales, Dala, Dima, Ditmarsker, Futura, Golden Acre, Håløyen Lundes, Københavns Torve, Marner Sepco, Resista, Respla, Ruhm von Enkhuizen, September, Toftegård, Văsternordland

f. rubra: Amager Tagenshus, Haco

convar. botrytis (L.) Alef.

var. botrytis: Erfurter, Erfurter Dvärg, Flora Blanca, Grandessa, Igloo, Stor dansk var. italica Plenck: Greenia, Waltham

convar. oleracea

var. gemmifera DC.: Jade

convar. acephala (DC.) Alef.

var. gongylodes L.: Wiener glas

var. sabellica L.: cv. unknown

var. viridis L.: cv. unknown

Brassica pekinensis (Lour.) Rupr.: cv. unknown

Brassica napus $\mathbf{L}$.

var. napobrassica (L.) Rchb.: Messukylän lanttu, Mustiala, Pandur, Svensk gul, Wilhelmsburger, Östgöta

Brassica campestris L.

var. rapifera Metz.

syn. B. rapa L. subsp. rapa: turnip Guldbåll, fodder turnip cv. unknown

Raphanus sativus $\mathbf{L}$. 


\section{References}

Ayers, G.W. 1972. Races of Plasmodiophora brassicae infecting crucifer crops in Canada. Canad. Plant. Dis. Survey 52: $77-81$.

Brokenshire, T. \& Lewis, S.J. 1981. Clubroot populations in S.E. Scotland. Proc. Brassica Conf. 1981: 12-23.

BuCZACKI, S.T. 1977. Root infections from single resting spores of Plasmodiophora brassicae. Trans. Brit. Mycol. Soc. 69: 328-329.

-, Мохнам, S.E. \& Turner, R.H. 1979. Some morphological features of the resting spore of Plasmodiophora brassicae. Trans. Brit. Mycol. Soc. 73: 343-347.

-, Toxopeus, H., Matrusch, P., Jonston, T.D., Dixon, G.R. \& Новоцтн, L.A. 1975. Study of physiologic specialization in Plasmodiophora brassicae: proposals for attempted rationalization through an international approach. Trans. Brit. Mycol. Soc. 65: 295-303.

Campbell, R.N., Greathead, A.S. \& Mrers, D.F. 1981. Clubroot in California. Proc. Brassica Conf. 1981: 11.

ChIANG, M.S. \& CRÉTE, R. 1972. Screening crucifers for germplasm resistance to clubroot Plasmodiophora brassicae. Can. Plant Dis. Surv. 52: 45-50.

- , CRETE, R. 1983. Transfer of resistance to race 2 of Plasmodiophora brassicae from Brassica napus to cabbage ( $B$. oleracea spp. capitata). V. The inheritance of resistance. Euphytica 32: 479-483.

-, Frechette, S., Kuo, C.G., Chong, C. \& Delafield, S.J. 1985. Embryogenesis and haploid plant production from anther culture of cabbage (Brassica oleracea var. capitata L.) Can. J. Plant Sci. 65: 10331037.

Crute, I.R., Gray, A.R., Crisp, P. \& Buczacki, S.T. 1980. Variation in Plasmodiophora brassicae and resistance to clubroot disease in brassicas and allied crops - a critical review. Pl. Breed. Abstr. 50: 91-104.

DeKhUIJZEN, H.M. 1979. Electron microscopic studies in the root hairs and cortex of a susceptible and a resistant variety of Brassica campestris infected with Plasmodiophora brassicae. Neth. J. Pl. Path. 85: 1-17.

Dixon, G.R., Jones, D.R. \& Ingram, D.S. 1981. Studies on populations of Plasmodiophora brassicae. Proc. Brassica Conf. 1981: 25-28.

Dobson, R.L., Robak, J. \& Gabrielson, R.L. 1983. Pathotypes of Plasmodiophora brassicae in Washington, Oregon and California. Pl. Dis. 67: 269-271.

Encke, F., Buchreim, G. \& Seybold, S. 1981. Zander Handwörterbuch der Pflanzennamen. 844p. 12. Aufl. Ulmer, Stuttgart. (Ref. Palmén, A. \& Alanko, P. 1983. Viljelykasvien nimistő. Puutarhaliiton opaskirj. 31, 152p. Helsinki.)

Heikinheimo, O. \& RaAtikainen, M. 1971. Paikan ilmoittaminen Suomesta tallennetuissa biologisissa aineistoissa. Ann. Ent. Fenn. 37: 1a: 1-30.

Heyn, F.W. 1981. Studies on clubroot populations. Proc. Brassica Conf. 1981: 29-34.
IKegami, H., Mukobata, H. \& NaIkI, T. 1978. Scanning electron microscopy of Plasmodiophora brassicae in diseased root cells of turnip and Chinese cabbage. (Studies on the clubroot of cruciferous plants III). Ann. Phytopath. Soc. Japan 44: 456-464.

Ingram, D.S. 1978. Internal life-cycling by Plasmodiophora brassicae Woron. during development of clubroot galls. Clubroot newsl. no. 6 1978: 10-11.

- \& Tommerup, I.C. 1972. The life history of Plasmodiophora brassicae Woron. Proc. Royal Soc., London, B. 180: 103-112.

Jamalainen, E.A. 1936. Tutkimuksia möhöjuuresta (Plasmodiophora brassicae Wor.). Referat: Untersuchungen über die Kohlhernie (Plasmodiophora brassicae Wor.) Staatl. Landw. Versuchstăt. Veröff. 85: 5-36.

Jones, D.R., Ingram, D.S. \& Dixon, G.R. 1982 a. Factors affecting tests for differential pathogenicity in populations of Plasmodiophora brassicae. Pl. Path. 31: 229-238.

- 1982 b. Characterization of isolates derived from single resting spores of Plasmodiophora brassicae and studies of their interaction. Pl. Path. 31: 239-245.

Jonsson, R. 1971. Rasproblem. Nord. Jordbr. forskn. 54: $158-160$.

- 1972. Undersökning rörande förekomst av raser av klumprot (Plasmodiophora brassicae Wor.) i Skåne. Sver. Utsädesför. Tidskr. 82: 83-87.

- 1981. Breeding for improved resistance to clubroot in oil rape. Proc. Brassica Conf. 1981: 44-46.

Keller, W.A. \& Armstrong, K.C. 1977. Embryogenesis and plant regeneration in Brassica napus anther cultures. Z. Pfl. zücht. 80: 100-108.

- 1979. Stimulation of embryogenesis and haploid production in Brassica campestris anther culture by elevated temperature treatments. Theor. Appl. Genet. 55: 65-67.

- 1983. Production of haploid via anther culture in Brassica oleracea var. italica. Euphytica 32: 151 -159 .

Krivchenko, V.I., Boos, G.V. \& Surmava, M.E. 1982. Harakteristika genofonda kapusty po ustojcivosti k Plasmodiophora brassicae Woron. Trudy po Prikladnoi Botanike, Genetike i Selektsii. 72: 113-120.

LAMMERINK, J. 1986. Identification of an eighth race of Plasmodiophora brassicae, the cause of clubroot, in New Zealand. N. Zealand J. Agric. Res. 29: 101-104.

LinNasalmi, A. 1948. Om bekämpandet av klumprotsjuka. Prakt. Försöksverks. 4: 87-88.

- 1952. Möhöjuuren torjunnasta ristikukkaisviljelyksillä. Maatal. ja Koetoim. 6: 74-83.

- 1959. The use of mercurous chloride in the control of clubroot J. Sci. Agric. Finland 31: 228.

- \& PAlonen, S. 1974. Om Plasmodiophora brassicaerasernas identifiering och kartering i Finland. Nord. Jordbr. forskn. 56: 6-10. 
— \& TIITtANEN, K. 1960. Merkurokloridi-lindaani-valmisteen käyttő kaalin möhöjuuren ja kărpästoukkien torjunnassa. Koetoim. ja käyt. 17: 17, 20.

- \& Tolviainen, A. 1981. Races of Plasmodiophora brassicae Wor. in Finland. Proc. Brassica Conf. 1981: 24. Prelim. Rep.

- \& Weisaeth, G. 1978. Om klumprotraser i Trøndelag Plasmodiophora rase 1, 7 og 9. Summary: Races of clubroot in Trøndelag, Norway. Res. Norw. Agric. 1978 29: 223-239.

Macfarlane, I. 1955. Variation in Plasmodiophora brassicae. Ann. Appl. Biol. 43: 297-306.

Murashige, T. \& Skoog, F. 1962. A revised medium for rapid growth and bioassays with tobacco tissue cultures. Physiol. Pl. 15: 473-497.

MurtomaA, A. \& Uotı, J. 1972. Effect of benomyl fungicide on cabbage clubroot. Ann. Agric. Fenn. 11: $330-332$.

Naikı, T., Tanahashi, K. \& Kageyama, K. 1984. The relationship between root hair infection with Plasmodiophora brassicea Wor. and subsequent club formation among cruciferous species. Ann. Phytopath. Soc. Japan 50: 211-215.

NowICKı, B. 1978. The identification of Plasmodiophora brassicae races in Poland. Phytopath. Z. 93: 181 -186 .

OCKENDON, D.J. 1984. Anther culture in Brussels sprouts (Brassica oleracea var. gemmifera). I. Embryo yields and plant regeneration. Ann. Appl. Biol. 105: 285 -291 .

RAINIO, A.J. 1930. Kaalirevennäinen ja sen levinneisyys. Maatalous 23: 275-278.

Reyes, A.A., Davidson, T.R. \& Marks, C.F. 1974. Races, pathogenicity and chemical control of Plasmodiophora brassicae in Ontario. Phytopath. 64: 173-177.

Rouxel, F., \& Sanson, M.T., Renard, M. \& Soum, B. 1983. Observations et premiers resultats de travaux sur la hernie dans les cultures de colza oleagineux $(B$. napus L.) en France. Pathotypes de Plasmodiophora brassicae et sensibilite varietale. Proc. Intern. Rapeseed Conf. 1983: 975-985.
StrandberG, J.O. \& Williams, P.H. 1967. Inheritance of clubroot resistance in Chinese cabbage. Phytopath. 57: 330 .

Tinggal, S.H. \& Webster, J. 1981. Technique for single spore infection by Plasmodiophora brassicae. Trans. Brit. Myc. Soc. 76: 187-190.

Toxopeus, H. 1974. The coding of races of Plasmodiophora brassicae (Woron.). Proc. Eucarpia Meeting Cruciferae 1974: 90-94.

-, Dixon, G.R. \& Matrusch, P. 1986. Physiological specialization in Plasmodiophora brassicae: An analysis by international experimentation. Trans. Brit. Mycol. Soc. 87: 279-287.

- \& JANSSEn, A.M.P. 1975. Clubroot resistance in turnip II. The 'slurry' screening method and clubroot races in the Netherlands. Euphytica 24: 751-755.

WeisAeth, G. 1972. Observasjoner vedrørende klumprot og Plasmodiophora-raser i Norge, i relasjon til problemer med sortsresistens og vekstforedling. Nord. Jordbr. forskn. 54: 160-163.

- 1977. Hodekålsortene 'Respla' og 'Resista' foredlinger med klumprotresistens. Inst. for grønnsakdyrking, Norges Landbr. høgsk. Meld. nr. 74: 937-939.

Williams, P.H. 1966. A system for determination of races of Plasmodiophora brassicae that infect cabbage and rutabaga. Phytopath. 56: 624-626.

- \& Seidel, D. 1968. Zum Vorkommen von Plasmodiophora brassicae-Rassen in der Deutschen Demokratischen Republik. Arch. Pfl.schutz 4: 31-36.

- \& WAlker, J.C. 1963. Races of clubroot in North America. Pl. Dis. Rep. 47: 608-611.

Woronin, M. 1876. Plasmodiophora brassicae, Urheber der Kohlpflanzen-Hernie. J. buch Wiss. Bot. 11: 548 -574. (Transl. C. Chupp Plasmodiophora brassicae The cause of cabbage hernia. Phytopath. classics 4: 9-31. Publ. Amer. Phytopath. Soc. 1934, Ithaca, N.Y.).

Yoshikawa, H. \& Buczacki, S.T. 1978. Clubroot in Japan: Research and Problems. Rev. Pl. Path. 57: 253-257.

Ms received July 18, 1991 
Möhöjuuritaudin ja Plasmodiophora

brassicae Wor. rotujen esiintyminen

Suomessa

\section{Annikki Linnasalmi ja Anneli Toiviainen}

Maatalouden tutkimuskeskus, Kasvinsuojelun tutkimuslaitos, Kasvitautien torjunnan tutkimusala

Jokioinen, Suomi

Tutkimuksessa selvitettiin möhöjuuritaudin ja Plasmodiophora brassicae Wor. patotyyppien esiintymistä ristikukkaisissa (Brassicaceae) vihanneskasveissa Suomessa v. 1974-1978. Tarkastetuista 101 kunnasta $81 \%$ :ssa esiintyi mőhöjuurta. Tauti oli yleisintă maan etelă- ja keskiosissa, mutta sită tavattiin myös ristikukkaiskasvien viljelyalueen pohjoisosissa $\left(66-67^{\circ} \mathrm{Pohj}\right.$. lev.). Kertyneistả 375 kasvinäytteestä $65 \%$ oli möhöjuurisia. Yleisimmin viljellyn kasvilajin, keräkaalin näytteistă (56 \% aineistosta) $68 \%$, kukkakaalinäytteistă ( $22 \%$ aineistosta) $63 \%$, muiden kaalilajien näytteistä (13\% aineistosta) $56 \%$ ja ristikukkaisista juurikasnäytteistä ( $19 \%$ aineistosta) $64 \%$ oli mőhöjuurisia. $P$. brassicae rotumääritykset tehtiin 90 näytteestã. Käytettiin Williamsin (1966) luoki- tussysteemiä. Eristetyt rodut olivat 1, 2, 3, 4, 6 ja 7. Rotu 2 oli ylivoimaisesti yleisin. Sitä tavattiin 32 kunnassa, rotuja 3, 4, 6 ja 7 kutakin 9-12 kunnassa, rotua 1 vain yhdessä kunnassa. Selviä eroja rotujen esiintymisessä maan eri osissa ei voitu todeta. Suoritettiin Williamsin ja ECD (Buczacki et al. 1975) luokitussysteemien vertailu. Williamsin systeemi todettiin nopeammaksi ja luotettavammaksi kuin ECD systeemi $P$. brassicae patotyyppien identifioimiseksi. Patotyypit mäăritettiin myös Norjassa ja Islannissa kerätystä möhöjuuriaineistosta.

Tutkimus on osa pohjoismaisesta möhöjuuriprojektista, NKJ-projekti 27 1974-1977: Möhöjuuren keståvyysjalostus, Plasmodiophora brassicae Wor. rodut sekă uusien torjunta-aineiden tehotutkimus. 